\title{
Detection of DNA Damages Induced by Five Model Chemi- cals in Goldfish Carassius auratus Cells Using Comet Assay
}

\author{
Takashi Ishikawa, Shin Ogata, Katsuzumi Okumura \\ and Hiroshi Taguchi*
}

Faculty of Bioresources, Mie University, 1515 Kamihama, Mie 514-8507, Japan

Received November 1, 2004; accepted January 5, 2005

\begin{abstract}
Summary Our aim is to develop and evaluate monitoring systems using aquatic organisms to assess the genotoxicity of water. We evaluated the genotoxicity of 5 model chemical mutagens by single cell gel electrophoresis (comet assay) using goldfish primary culture cells. The cells were collected at $3 \mathrm{~h}$ after treatment of each mutagen. Treatments with an alkylating agent (MNNG), a DNA oxidative agent $\left(\mathrm{H}_{2} \mathrm{O}_{2}\right)$, a DNA crosslinking agent (MMC), an RNA polymerase inhibitor (Actinomycin D), and a topoisiomerase inhibitor (VP-16) induced DNA fragmentation. All of tested chemicals induced DNA damage fragmented by dose- and time-dependently except MMC. Since the comet assay detects genotoxicity as DNA fragmentation, this result shows that the comet assay using fish cells are suitable for the monitoring of environmental genotoxicity.
\end{abstract}

Key words Comet assay, DNA damage, MNNG, Hydrogen peroxide, Mitomycin C, VP-16, Actinomycin D, Fish cells.

Bacteria, yeast, cultured cells of mammalian and rodents are commonly used to assay the genotoxicity of chemicals. The comet assay is a rapid, sensitive and inexpensive method for measuring DNA strand breaks and DNA repair. One of its advantages is that it can be applied to any proliferating cell population regardless of its karyotype. Because fish chromosomes are small, metaphase analysis of chromosomal aberrations is difficult. On the other hand, the comet assay can evaluate genotoxicity by miglation of DNA. Therefore, small size and large number of chromosome do not affect the performance of the comet assay, so it can be easily applied to fish or other aquatic organisms. The comet assay have been developed for fish (Michelmore and Chipman 1998; Faverney 2001; Masuda et al. 2004) and other aquatic organisms, including shellfish (Sasaki et al. 1997), mussel (Pavlica et al. 2001), oyster (Nacci et al. 1996), grass shrimp (Lee et al. 2000), and tadpoles (Ralph and Petras 1996). In fish and other aquatic organisms, it is a problem that fundamental knowledge to evaluate genotoxicity is scarce. Specifially, there are very few reports about timecourse study on DNA repair in fish cells (Walton et al. 1983; Miller et al. 1989; Chen and Yew 1988). To evaluate the comet assay using fish cells for monitoring the genotoxicity of chemicals and contaminants in water environment, we studied DNA damage and repair in the primary culture cells of a goldfish, Carassius auratus, exposed to 5 model chemical mutagens with different modes of action.

Materials and methods

Fish and primary cell culture

A gold fish (Carassius auratus, $4-5 \mathrm{~cm}$ in body length) cell growth was obtained via primary

* Corresponding author, e-mail: hiroshi@bio.mie-u.ac.jp 
culture. Sections of dorsal fin were removed and placed in phosphate bufferd salin $\left(\mathrm{Ca}^{2+}, \mathrm{Mg}^{2+}\right.$ free), containing antibiotics. The dorsal fin was then cut approximately $3 \mathrm{~mm}$ and washed twice with fresh PBS(-) to dilute any possible microbial contaminants present on the mucosal. A number of fragments were placed in a cell culture dish $(35 \mathrm{~mm}$, Falcon, USA) containing $2 \mathrm{ml}$ of culture medium (Alpha MEM, Gibco BRL Co., USA) containing 10\% (v/v) fetal bovine serum, $100 \mu \mathrm{g} / \mathrm{ml}$ streptomycin, $100 \mathrm{U} / \mathrm{ml}$ penicillin $\mathrm{G}$, and $2 \mathrm{mM} \mathrm{L}$-gultamine. Cultures were maintained in $\mathrm{CO}_{2}$ incubator at $27^{\circ} \mathrm{C}$ in $3 \% \mathrm{CO}_{2}$ atmosphere.

\section{Cell treatment}

Cells were seeded into a dish at approximately 30,000 cells/dish and incubated at $27^{\circ} \mathrm{C}$ in $3 \%$ $\mathrm{CO}_{2}$ for $24 \mathrm{~h}$. Mutagen treatment was carried out for $15 \mathrm{~min}$ with the indicated concentrations of each mutagen. Cells were washed with PBS(-) and incubated for $3 \mathrm{~h}$. $N$-methyl- $N N^{\prime}-$ nitro- $N$ nitrosoguanidine (MNNG, CAS 70-25-7, Nakalai Tesuque, Japan) and VP-16 (CAS 33419-42-0, Wako Pure Chemical Industries Ltd., Japan) were dissolved in dimethyl sulfoxide (DMSO). Hydrogen peroxide $\left(\mathrm{H}_{2} \mathrm{O}_{2}\right.$, CAS 722-84-1, Santokukagaku, Japan) and Mitomycin C (MMC, CAS 50-077, Kyowa Hakko Kogyo, Japan) were dissolved in distilled water. Actinomycin D (CAS 50-76-0, Sigma-Aldrich Co., USA) was dissolved in ethyl alcohol. When solvent was used, its final concentration in medium was kept less than $0.1 \%(\mathrm{v} / \mathrm{v})$. Control cells were treated with distilled water in culture medium. For time-course study, cells were treated with each mutagen for $15 \mathrm{~min}$. At the end of the treatments, cells were washed with PBS(-) and incubated for 3, 6 and $12 \mathrm{~h}$ with each mutagen. After this treatment, DNA damage was measured by comet assay.

\section{Observation of survival rates}

Cell viability was determined by methyl-thiazolyl tertrazolium (MTT, Nakalai Tesque Inc., Japan) assay using 24-well microplate. At the end of the treatments, cells were incubated with MTT $(0.5 \mathrm{mg} / \mathrm{ml}$ final concentration) for $4 \mathrm{~h}$, then isopropyl alcohol containing $0.04 \mathrm{~N} \mathrm{HCl}$ was added. Amount of formazan formed was assayed spectrophotometrically at wavelength between 550 and $600 \mathrm{~nm}$ with a microplate reader for 96-well plates (Tosoh Co., MPR-A4i II, Japan).

\section{Detection of DNA damage}

The comet assay was performed under alkaline conditions described by Singh et al. (1988) with some modifications. Treated cells were collected and embedded in a layer of $0.75 \%$ low-melting agarose (TAKARA Bio. Inc, Japan) sandwiched between a bottom layer of $0.75 \%$ normal-melting agarose (Roche Diagnostics K.K. Germany) and a top layer of $0.75 \%$ low-melting agarose (TAKARA Bio. Inc, Japan) on a fully frosted microscopic slide (Matsunami Glass. Japan). The slide was placed in a lysis solution containing $2.5 \mathrm{M} \mathrm{NaCl}, 100 \mathrm{mM} \mathrm{Na}_{2}$ EDTA, $10 \mathrm{mM}$ Tris, $10 \%$ DMSO and $1 \%$ Triton X-100 for up to $1 \mathrm{~h}$. The slides were placed on a horizontal gel electrophoresis platform and covered with an alkaline solution made up of $300 \mathrm{mM} \mathrm{NaOH}$ and $1 \mathrm{mM} \mathrm{Na}$ EDTA. The slides were left in the solution for $20 \mathrm{~min}$ to allow unwinding of the DNA. Electrophoresis was conducted with the same solution for $20 \mathrm{~min}$ at $30 \mathrm{~V}(1 \mathrm{~V} / \mathrm{cm})$ and $250 \mathrm{~mA}$. After electrophoresis the slides were neutralized using $0.4 \mathrm{M}$ Tris- $\mathrm{HCl}$ buffer $(\mathrm{pH} 7.5)$. Each slide was stained with $50 \mu \mathrm{l}$ ethidium bromide $(20 \mathrm{mg} / \mathrm{ml})$. We examined 50 nuclei on one slide at $200 \times$ magnification using a fluorescence microscope (Zeiss, Axioskop) connected to a CCD camera (Photometrics, PXL1400-C3) and personal computer (Apple, Macintosh Quadra 840av). Each experiment was carried out in triplicate.

\section{Statistics}

A $t$-test was used to evaluate the significance of the differences in the DNA damage in the comet assay between cells treated with mutagen and control. 


\section{Results}

Table 1 and Table 2 show survival rates and DNA damage in the goldfish cells after exposure to 5 model mutagens. The DNA damage was evaluated by DNA percentage in the comet tail. Fig.1 shows typical comet images, which were obtained after treatments of 5 model chemical mutagens with different modes of action. No or little migration of DNA contents was observed in control cells. As for MNNG, significant difference from control $(p<0.01)$ was observed with fish cells only at $10 \mu \mathrm{M}$ (Fig. 2A). $\mathrm{H}_{2} \mathrm{O}_{2}$, Actinomycin D and VP-16 treatment led to dose-dependent increases in DNA migration from nucleus (Fig. 2B, D and E). Treatment of Actinomycin D showed the highest sensitivity. In contrast, MMC treatment was ineffective in altering DNA migration at all concentrations investigated up to the maximum concentration of $10 \mu \mathrm{M}$ (Fig. 2C). MNNG induced DNA damage 3, 6 and $12 \mathrm{~h}$ after treatment, and maximum response was detected at $6 \mathrm{~h}$ after treatment (Fig. 2F). The effect of $\mathrm{H}_{2} \mathrm{O}_{2}$ and VP-16 was similar to that of MNNG (Fig. $2 \mathrm{G}$ and $\mathrm{J}$ ). The maximum response was induced by actinomycin D $3 \mathrm{~h}$ after treatment, and it decreased time-dependently (Fig. 2I). On the other hand, MMC induced a positive response only $12 \mathrm{~h}$ after treatment (Fig. 2H).

\section{Discussion}

We examined DNA damage and survival rates in the primary culture cells of a goldfish, Carassius auratus, exposed to mutagens with different modes of action. In fish cells, the DNA damage was induced by lower concentration of MNNG and $\mathrm{H}_{2} \mathrm{O}_{2}$ compared with Chinese hamster lung fibroblasts V79 cells (Horvathova 1998). This high mutagen-sensitivty is advantage for environmental genotoxicity monitoring. The comet assay can detect directly DNA strand breaks, which may be induced rapidly, such as $1 \mathrm{~h}$ after exposure to genotoxic agents. In order to detect the DNA damage by Comet assay, cells were collected before the induction of the repair system. In this study, the DNA repair was incomplete in goldfish cells at $12 \mathrm{~h}$ after treatment (Fig. 2F, G, I and J). A similar conclusion was drawn from un-

Table 1. DNA damage and cytotoxcity in goldfish at different concentrations at $3 \mathrm{~h}$ after treatment with five model chemical mutagens

\begin{tabular}{lccr}
\hline $\begin{array}{c}\text { Test } \\
\text { substances }\end{array}$ & $\begin{array}{c}\text { Dose } \\
(\mu \mathrm{M})\end{array}$ & $\begin{array}{c}\text { Tail DNA } \\
\% \pm \text { S.D. }\end{array}$ & $\begin{array}{c}\text { Cell viability } \\
(\% \text { of control })\end{array}$ \\
\hline Control & & $9.75 \pm 8.77$ & 100.0 \\
MNNG & 0.1 & $10.73 \pm 9.10$ & 108.1 \\
& 1 & $12.53 \pm 10.01$ & 102.6 \\
$\mathrm{H}_{2} \mathrm{O}_{2}$ & 10 & $69.22 \pm 21.71$ & 97.6 \\
& 0.1 & $22.71 \pm 11.62$ & 102.6 \\
& 1 & $40.30 \pm 14.10$ & 110.3 \\
$\mathrm{MMC}$ & 10 & $47.58 \pm 20.01$ & 96.0 \\
& 0.1 & $14.57 \pm 10.37$ & 93.5 \\
Actinomycin D & 1 & $14.67 \pm 7.90$ & 94.4 \\
& 0.01 & $11.02 \pm 9.44$ & 95.6 \\
VP-16 & 0.1 & $61.18 \pm 19.95$ & 97.1 \\
& 1 & $64.08 \pm 17.01$ & 97.5 \\
& 0.1 & $33.21 \pm 15.70$ & 100.0 \\
& 1 & $44.45 \pm 19.95$ & 95.7 \\
& 10 & $64.08 \pm 17.01$ & 79.9 \\
\hline
\end{tabular}

Table 2. DNA damage and cytotoxcity in goldfish at different sampling times after treatment with 5 model chemical mutagens

\begin{tabular}{|c|c|c|c|}
\hline $\begin{array}{c}\text { Test } \\
\text { substance } \\
\text { (dose) }\end{array}$ & $\begin{array}{l}\text { Incubation } \\
\text { time (h) }\end{array}$ & $\begin{array}{l}\text { Tail DNA } \\
\% \pm \text { S.D. }\end{array}$ & $\begin{array}{c}\text { Viability } \\
\text { (\% of control) }\end{array}$ \\
\hline \multirow[t]{3}{*}{ Control } & 3 & $9.75 \pm 8.77$ & 100.0 \\
\hline & 6 & $9.86 \pm 5.72$ & 100.0 \\
\hline & 12 & $7.64 \pm 6.14$ & 100.0 \\
\hline \multirow[t]{3}{*}{$\mathrm{MNNG}(10 \mu \mathrm{M})$} & 3 & $69.22 \pm 21.71$ & 97.6 \\
\hline & 6 & $82.01 \pm 13.89$ & 93.7 \\
\hline & 12 & $72.01 \pm 10.00$ & 93.7 \\
\hline \multirow[t]{3}{*}{$\mathrm{H}_{2} \mathrm{O}_{2}(10 \mu \mathrm{M})$} & 3 & $47.58 \pm 20.08$ & 96.0 \\
\hline & 6 & $50.86 \pm 23.66$ & 94.7 \\
\hline & 12 & $42.20 \pm 11.72$ & 94.1 \\
\hline \multirow[t]{3}{*}{$\mathrm{MMC}(10 \mu \mathrm{M})$} & 3 & $11.02 \pm 17.50$ & 95.6 \\
\hline & 6 & $11.29 \pm 11.42$ & 100.6 \\
\hline & 12 & $16.05 \pm 9.25$ & 98.3 \\
\hline \multirow{3}{*}{$\begin{array}{l}\text { Actinomycin D } \\
(1 \mu \mathrm{M})\end{array}$} & 3 & $64.08 \pm 17.01$ & 97.4 \\
\hline & 6 & $61.58 \pm 22.41$ & 89.7 \\
\hline & 12 & $45.53 \pm 15.87$ & 96.4 \\
\hline \multirow[t]{3}{*}{ VP-16 (10 $\mu \mathrm{M})$} & 3 & $41.91 \pm 17.41$ & 79.9 \\
\hline & 6 & $65.38 \pm 17.09$ & 87.0 \\
\hline & 12 & $31.28 \pm 17.79$ & 103.5 \\
\hline
\end{tabular}



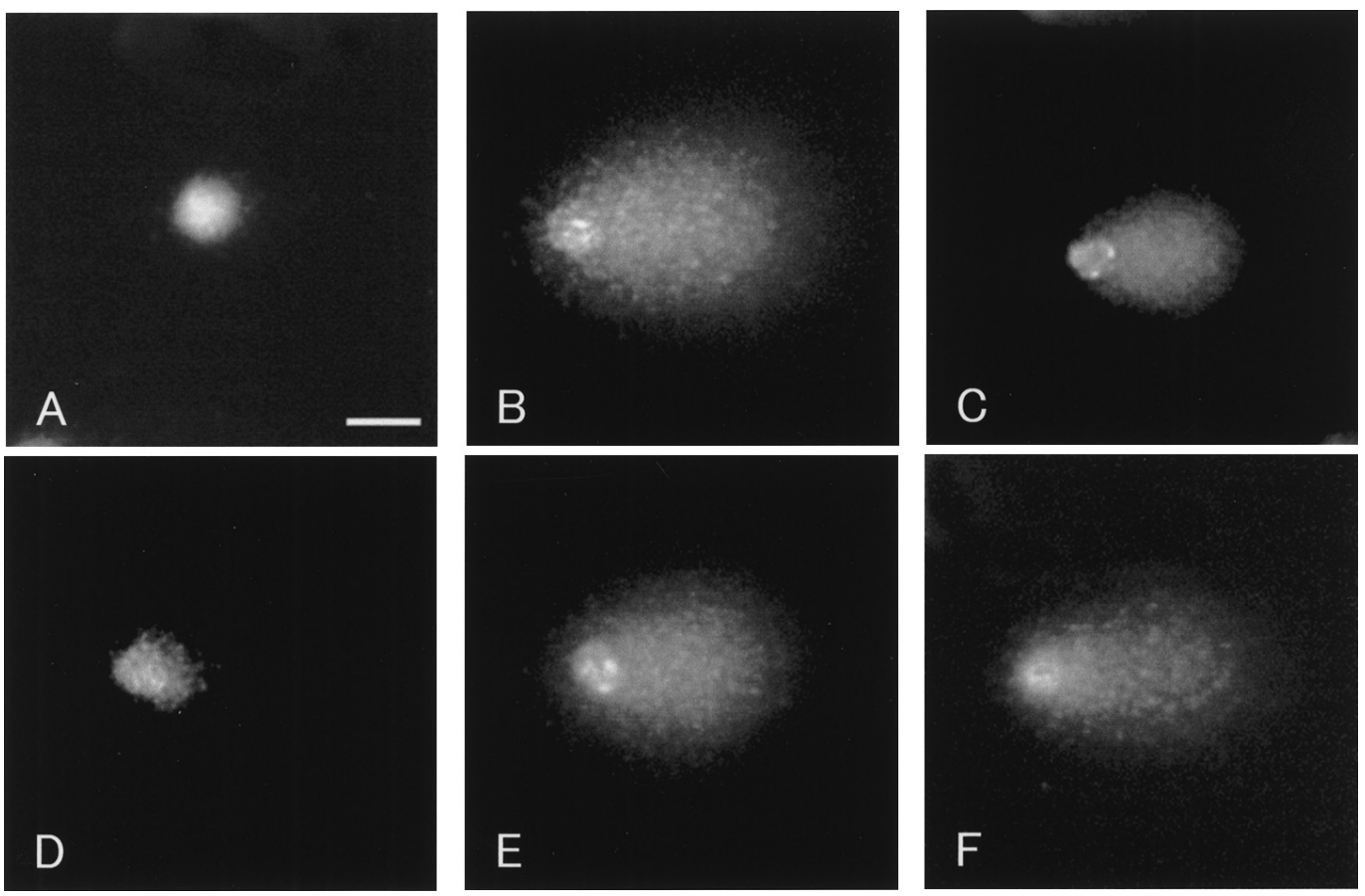

Fig. 1. Typical image of damaged nucleus observed after the treatment of 5 model chemical mutagens. Control (A), MNNG (B), $\mathrm{H}_{2} \mathrm{O}_{2}$ (C), MMC (D), Actinomycin D (E), and VP-16 (F). Bar scale $=10 \mu \mathrm{m}$.

scheduled DNA repair synthesis assay (Walton et al. 1983). These results suggest that DNA repair activity in fish is low. The positive responses by MNNG, $\mathrm{H}_{2} \mathrm{O}_{2}$, Actinomycin D and VP-16 did not decreased with time, suggesting that the DNA damage was not repaired, and that damage is detectable in comet assay during long sampling times. On the other hand, MMC did not lead to a positive response in high concentration treatment in this study (Fig. 2H). However, MMC induces sister-chromatid exchange (Barker and Rackham 1979) and chromosome aberrations (Hayashi et al. 1998; Ishikawa et al. 2001) on fish cells. These results suggest MMC induces DNA damage on fish cells. MMC causes DNA crosslinking lesions that inhibit DNA unwinding and fragmentation. However, Miyamae et al. (1998) reported that DNA migration in mouse lymphoma cells significantly increases at $21 \mathrm{~h}$ after treatment. Therefore, such long time incubation might also yield a clearly detectable DNA damage. Daza et al. (2002) shows that actinomycin D itself provoked DNA strandbreaks even when the cells were in G0. Therefore, in our opinion, DNA damage was observed rapidly after treatment (Fig 2D). The results obtained from VP-16 treatment indicate similar as Actinomycin D treatment. Godard et al. (2002) reported that topoisomerase inhibitor, VP-16 induces DNA strand breaks in Chinese hamster ovary cells, our results support that report.

The DNA damage was increased dose-dependently on all tested mutagens of those which demonstrated positive results by comet assay. We conclude from the results described above that the comet assay using fish cells may provide good tools to assess the genotoxicity not only of contamination in environmental waters but also laboratory alternatives to rodents or other mammalian systems. 

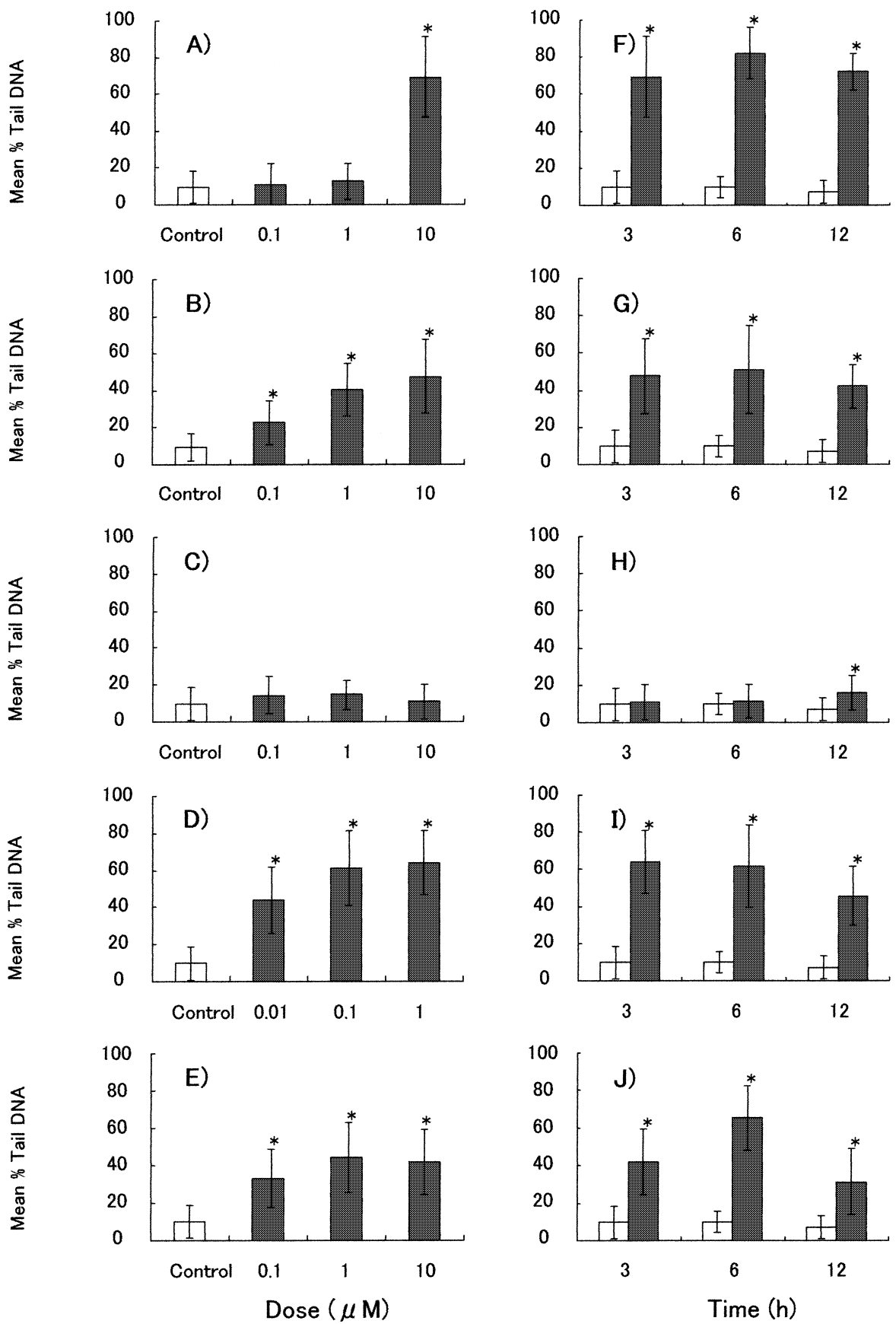

Fig. 2. Result of the comet assay expressed in terms of the tail DNA percentage in goldfish cells treated with 5 model chemical mutagens. Graph demonstrates responses to MNNG (A, F), $\mathrm{H}_{2} \mathrm{O}_{2}$ (B, G), MMC (C, H), actinomycin D (D, I), and VP-16 (E, J). Error bar shows mean \pm S.D. * indicates significant different from control data at $p<0.01$, based on $t$-test. 


\section{References}

Barker, C. J. and Rackham, B. D. 1979. The induction of sister-chromatid exchanges in cultured fish cells (Ameca splendens) by carcinogenic mutagens. Mutat. Res. 68: 381-387.

Chen, J. D. and Yew, F. H. 1988. DNA replication and repair of Tilapia cells. II. Effects of temperature on DNA replication and ultraviolet repair in Tilapia ovary cells. J. Cell Sci. 89: 263-272.

Daza, P., Torreblanca, J., Garcia-Herdugo, G. and Moreno, F. J. 2002. DNA strand-breaks induced by the topoisomerase I inhibitor camptothecin in unstimulated human white blood cells. Cell Biol. Int. 26: 707-713.

Godard, T., Deslandes, E., Sichel, F., Poul, J. M. and Gauduchon, P. 2002. Detection of topoisomerase inhibitor-induced DNA strand breaks and apoptosis by the alkaline comet assay. Mutat. Res. 520: 47-56.

Hayashi, M., Ueda, T., Uyeno, K., Wada, K., Kinae, N., Saotome, K., Tanaka, N., Takai, A., Sasaki, Y. F., Asano, N., Sofuni T. and Ojima, Y., 1998. Development of genotoxicity assays systems that use aquatic organisms. Mutat. Res. 399: $125-133$.

Ishikawa, T., Takai, A. and Ueno, K. 2001. Chromosomal aberrations and survival in normal and dechorionated embryos of Misgurnus anguillicaudatus (Cobitidae pisces) exposed to mitomycin C. Cytologia 66: 215-219.

Lee, R., Kim, G. B., Maruya, K. A., Steinert, S. A. and Oshima, Y., 2000. DNA strand breaks (comet assay) and embryo development effects in grass shrimp (Palaemonetes pugio) embryos after exposure to genotoxicants. Mar. Environ. Res. 50: 553-557.

Masuda, S., Deguchi, Y., Masuda, Y., Watanabe, T., Nukaya, H., Terao, Y., Takamura, T., Wakabayashi, K. and Kinae, N. 2004. 2-[2-(acetylamino)-4-[bis(2-hydroxyethyl)amino]-5-methoxyphenyl]-5-amino-7-bromo-4-chloro-2H-benzotriazole (PBTA-6) and 4-amino-3,3'-dichloro-5,4'-dinitro-biphenyl (ADDB) in goldfish (Carassius auratus) using the micronucleus test and the comet assay. Mutat. Res. 560: 33-40.

Michelmore, C. L. and Chipman, J. K. 1998. DNA strand breakage in aquatic organisms and the potential value of the comet assay in environmental monitaring. Mutat. Res. 399: 135-147.

Miller, M. R., Balair, J. B. and Hinton, D. E. 1989. DNA repair synthesis in isolated rainbow trout liver cells. Carcinogenesis 10: 995-1001.

Miyamae, Y., Zaizen, K., Ohara, K., Mine, Y. and Sasaki,Y. F. 1998. Detection of DNA lesions induced by chemical mutagens by the singel cell gel electrophoresis (Comet) assay. 1. Relationship between the onset of DNA damage and the characteristics of mutagens. Mutat. Res. 415: 229-235.

Nacci, D. E. Cayula, S. and Jackim, E. 1996. Detection of DNA damage in individual cells from marine organisms using the single cell gel assay. Aquat. Toxicol. 35: 197-210.

Pavlica, M., Klobučar, G. I. V., Mojaš, N., Erben, R. and Papeš, D. 2001. Detection of DNA damage in haemocytes of zebra mussel using comet assay. Mutat. Res. 490: 209-214.

Ralph, S. and Petras, M. 1998. Caged amphibian tadpoles and in situ genetoxicity monitoring of aquatic environments with the alkaline single cell gel electrophresis (Comet) assay. Mutat. Res. 413: 235-250.

Sasaki, Y. F., Izumiyama, F., Nishidate, E., Ishibashi, S., Tsuda, S., Matsusaka, N., Asano, N., Saotome, K., Sofuni, T. and Hayashi, M. 1997. Detection of genotoxicity of polluted sea water using shellfish and the alkaline single-cell gel electrophoresis (SCE) assay: A preliminary sutudy. Mutat. Res. 393: 133-139.

Singh, N. P., McCoy, M. T. Tice, R. R. and Schneider, E. L. 1988. A simple technique for quantitation of low levels of DNA damage in individual cells. Exp. Cell Res. 75: 184-191.

Walton, D. G., Acton, A. B. and Stich, H. F. 1983. DNA repair synthesis in cultured mammalian and fish cells following exposure to chemical mutagens. Mutat. Res. 124: 153-161. 